\title{
Multiple atypical recurrent meningiomas 13 years after radiotherapy for unilateral retinoblastoma: case report and review of the literature
} Mnogie atypowe nawrotowe oponiaki po 13 latach od radioterapii z powodu
jednostronnego siatkówczaka: opis przypadku i przeglad piśmiennictwa

Yavuz Aras', Mehmet Osman Akcakaya', Aydin Aydoseli', Rasim Meral', Talat Kiris'

'Department of Neurosurgery, Istanbul School of Medicine, Istanbul University, Istanbul, Turkey

2Institute of Oncology, Istanbul School of Medicine, Istanbul University, Istanbul, Turkey

\begin{abstract}
Radiotherapy is an important treatment modality for intracranial malignancies. Improved survival rates were achieved via a combination of surgery, chemotherapy and radiotherapy. On the other hand, improved survival rates made long-term complications of radiotherapy more apparent. Secondary neoplasms due to cranial irradiation are encountered more commonly in neurosurgical practice. Radiation-induced meningiomas are recognized as a common late complication of radiotherapy. However, radiation-induced meningiomas after radiotherapy for retinoblastoma have been reported rarely. Herein we report a patient who harboured multiple meningiomas 13 years after radiotherapy for unilateral retinoblastoma, which were recurrent despite surgical removal and chemotherapy.
\end{abstract}

Key words: radiotherapy, meningioma, radiation-induced tumour, secondary brain neoplasms in children, retinoblastoma.

\section{Introduction}

In the last three decades, a combination of surgery, new chemotherapy regimens and radiotherapy has improved survival rates in the management of malignancies. However, longer survival allowed late effects of radiotherapy to become apparent. Long-term effects

\section{Streszczenie}

Radioterapia jest ważną metodą leczenia złośliwych guzów śródczaszkowych. Dzięki łącznemu stosowaniu leczenia chirurgicznego, chemioterapii i radioterapii osiąga się zwiększony odsetek przeżyć, ale jednocześnie sprawia to, że częściej ujawniają się odległe powikłania radioterapii. Guzy wtórne do napromieniania w obrębie głowy są znanymi i częstymi powikłaniami radioterapii. Rzadko opisywano jednak oponiaki wywołane napromienianiem prowadzonym $z$ powodu siatkówczaka. W niniejszym artykule opisano przypadek pacjenta, u którego po 13 latach od radioterapii z powodu jednostronnego siatkówczaka wystąiły mnogie oponiaki, które miały charakter nawracający mimo leczenia chirurgicznego i chemioterapii.

Słowa kluczowe: radioterapia, oponiak, guz wywołany napromienianiem, wtórne guzy mózgu u dzieci, siatkówczak.

of radiotherapy such as radiation necrosis, arteritis, leukoencephalopathy and radiation-induced tumours are well known [1-3]. Radiation-induced meningiomas are usually aggressive and multiple, with a high recurrence rate after surgical treatment [1,3-6]. We present a case of a patient who harboured multiple atypical meningiomas, which were recurrent after surgical resection,

Correspondence address: Mehmet Osman Akcakaya, MD, Istanbul Universitesi Istanbul Tip Fakultesi Norosiruriji Anabilim Dalı, Norolojik Bilimler binası 6.kat Çapa/Fatih/istanbul 34093, phone: 00905322557774, e-mail: moakcakaya@gmail.com

Received: 8.12.2011; accepted: 8.03.2012 
13 years after the initial radiotherapy for unilateral retinoblastoma.

\section{Case report}

A 13-year old boy was admitted to our outpatient clinic with severe headache continuing for the last three months. His neurological examination was normal.

He had been diagnosed in our institution with a unilateral retinoblastoma of the right eye, when he was 6 months old. No tumour invasion was detected in the contralateral eye or in the cranium. Enucleation of the involved eye was then performed. The pathological examination was consistent with retinoblastoma. The patient was then treated with multimodal chemotherapy for a period of 6 months, and right orbital radiotherapy of a total dose of $40 \mathrm{~Gy}$ in 20 fractions.

After 13 years of a disease-free follow-up period, the patient presented with severe headache. Gadoliniumenhanced magnetic resonance imaging (MRI) scan revealed an extra-axial mass lesion in the right mid-cranial fossa, with homogeneous diffuse contrast enhancement (Fig. 1). Surgery was planned and the lesion was totally removed along with the affected dura (Fig. 2). The patient's postoperative course was uneventful. The pathology report was consistent with atypical meningioma (WHO grade II). The mean proliferation index was high (Ki-67 20\%).

Systemic chemotherapy of 3 courses (vincristine $1.5 \mathrm{mg} / \mathrm{m}^{2}$, cyclophosphamide $600 \mathrm{mg} / \mathrm{m}^{2}$, cisplatin
$100 \mathrm{mg} / \mathrm{m}^{2}$, etoposide $150 \mathrm{mg} / \mathrm{m}^{2}$ ) was given, and the patient was followed up by both neurosurgery and oncology outpatient clinics. Fifteen months after the surgical resection, the patient experienced severe headache and visual deterioration in his left eye. Neurological examination was normal. Control MRI scans indicated a bifrontal extra-axial mass lesion with compression to the left optic nerve, and bilateral internal carotid artery (ICA) and cavernous sinus infiltration (Fig. 3). A bicoronal incision, with use of the existing right pterional craniotomy and an additional right frontal craniotomy, $2 \mathrm{~cm}$ crossing the midline, was performed; the lesion was subtotally removed with the affected dura, as the bilateral adhesion of tumour to ICA made a total resection impossible. The postoperative MRI scan showed a remnant of the tumour left on the planum sphenoidale and tuberculum sella level. The patient was discharged from hospital on the sixth postoperative day with no neurological deficit. The pathology report was consistent with atypical meningioma. The mean proliferation index was $25-30 \%$ (Ki-67).

\section{Discussion}

Radiation-induced tumours (RITs) are a well-known late complication of cranial radiotherapy. The actual incidence of RITs is not exactly known, but considered to be low. The most common RITs are meningiomas, low or high grade gliomas, and sarcomas $[1,7]$. Meningiomas are tumours of the brain and spinal cord, arising
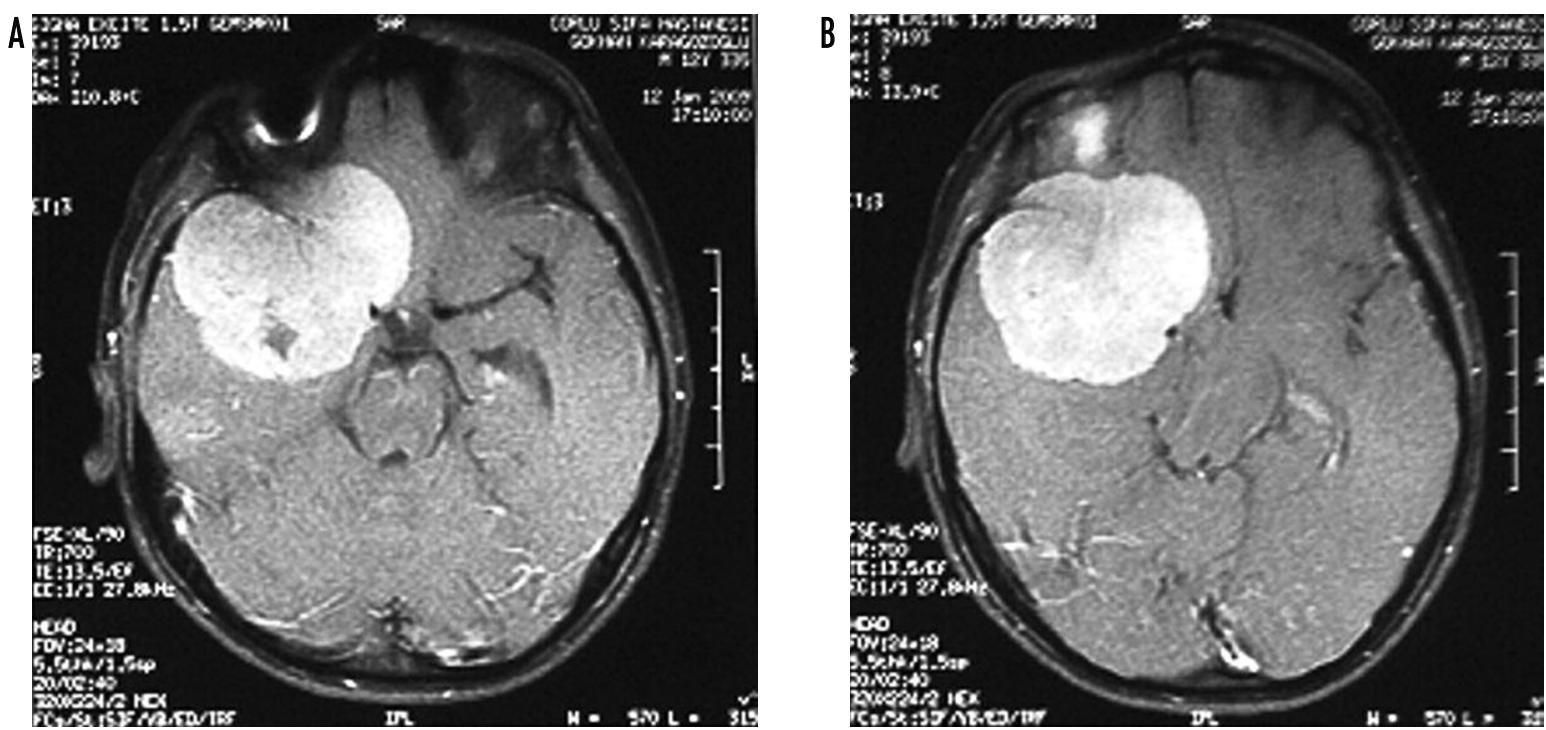

Fig. 1. Gadolinium-enhanced magnetic resonance imaging scan revealed an extra-axial mass lesion $(58 \times 62 \times 50 \mathrm{~mm})$ in the right mid-cranial fossa, with homogeneous diffuse contrast enhancement 

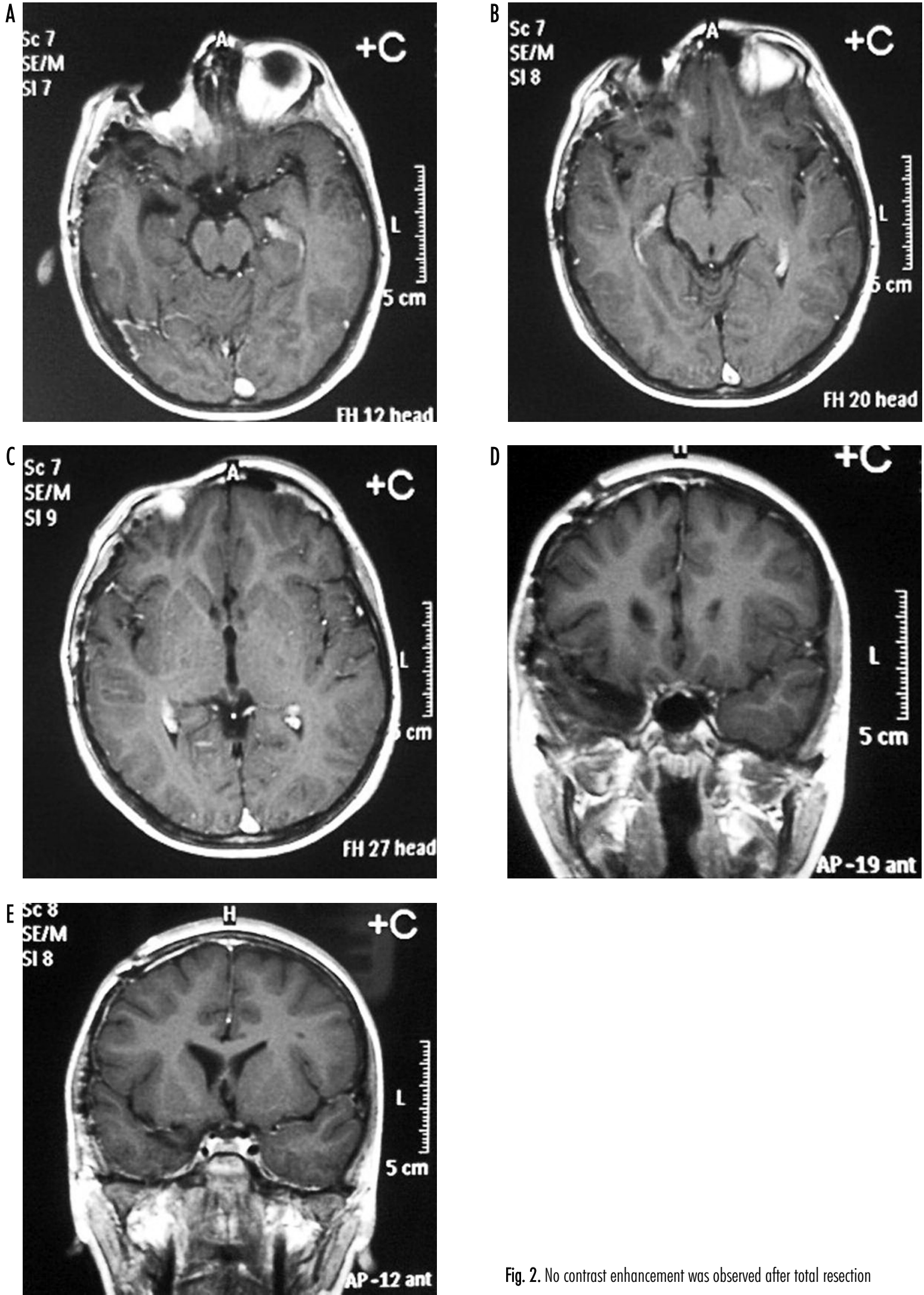

Fig. 2. No contrast enhancement was observed after total resection 
A

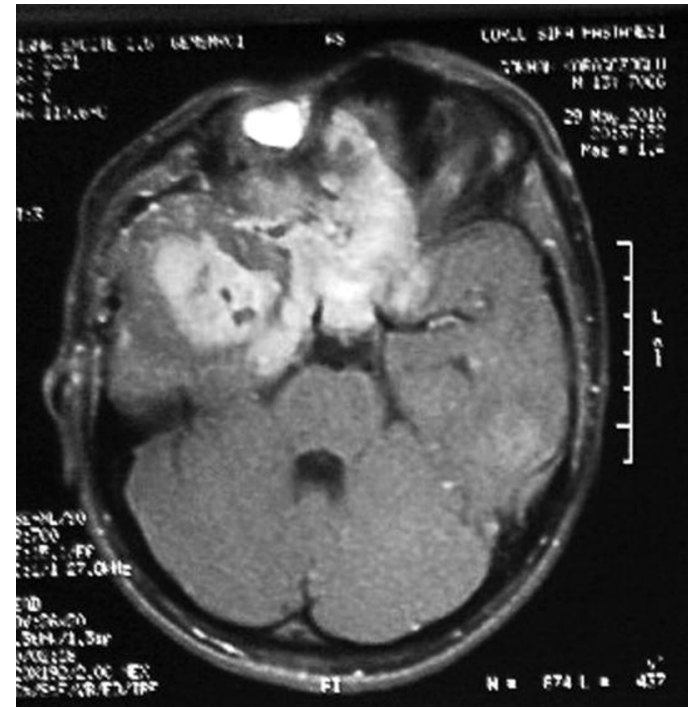

C

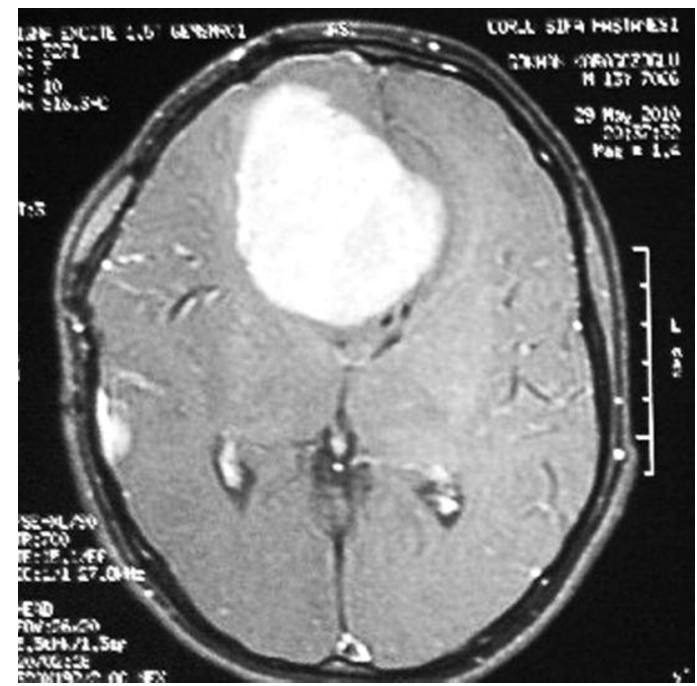

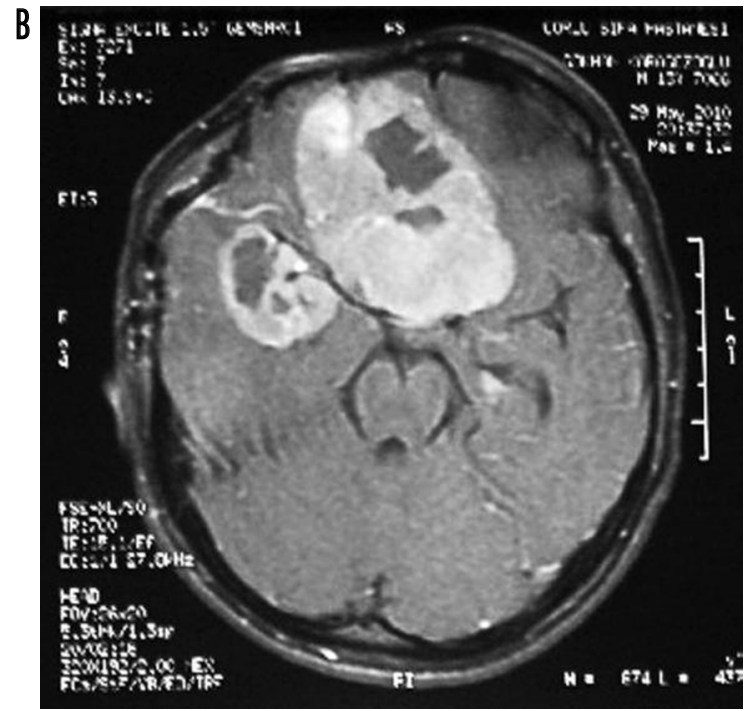

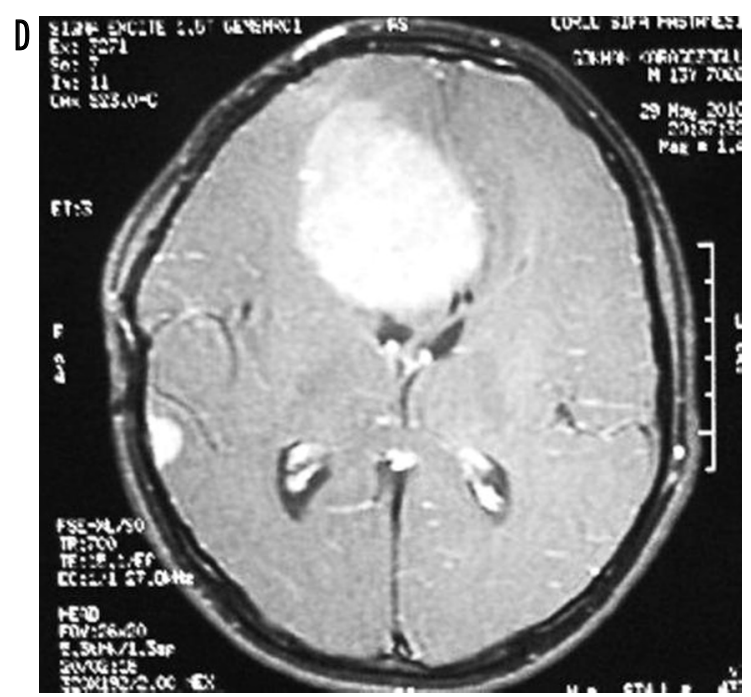

Fig. 3. Bifrontal extra-axial mass lesion $(55 \times 62 \times 57 \mathrm{~mm})$ with compressed left optic nerve, and bilateral internal carotid artery and cavernous sinus infiltration

from the arachnoid cap cells on the external layer of the arachnoid membrane [8]. The arachnoidal tissue is sensitive to irradiation, and especially in the paediatric age group, it is open to oncogenic stimulation [9]. Meningiomas are comparatively rare in infants and children, with an incidence from $0.4 \%$ to $4.6 \%$, mostly associated with neurofibromatosis and previous irradiation $[10,11]$.

Retinoblastoma is the most common primary intraocular malignancy in children. Two different forms of retinoblastoma are known: hereditary and nonhereditary. The hereditary form tends to be bilateral and familial with an autosomal dominant inheritance pattern, whereas the nonhereditary form is expected to be uni- lateral and caused by somatic mutations in a single retinal cell $[12,13]$. Tumours following radiotherapy for retinoblastoma have been reported only in a limited number of publications [14-21]. Hereditary (bilateral) retinoblastomas in children caused by germline mutations in the $R B 1$ gene also increase the risk of developing a non-malignant second primary tumour. In contrast, most patients with unilateral retinoblastoma (> 85\%) do not have these mutations [2]. Although there is an elevated risk for second primary tumours in patients with unilateral retinoblastoma, it is considerably lower than in patients with bilateral retinoblastoma.

The criteria for a tumour to be defined as radiationinduced was previously described $[7,22]$. There are many 
risk factors which may be responsible for the development of an RIT, such as radiation type and dose, additional chemotherapy, tissue vulnerability, underlying disease, age at irradiation, genetic predisposition to malignancies and genetic polymorphism in certain enzymes [23,24].

Harrison et al. [5] classified radiation-induced meningiomas into 3 categories: those due to high dose ( $>20 \mathrm{~Gy}$ ), intermediate dose (10-20 Gy) and low dose $(<10 \mathrm{~Gy})$. Patients exposed to irradiation at younger ages tend to develop meningioma in a shorter period and high dose radiation is established as an independent risk factor [25]. Harrison et al. [5] reported a latency period of 35.2 years after low dose irradiation, 26.1 and 19.5 years after intermediate and high dose irradiation, respectively. Similar latency periods have been reported by many authors. Although the latency period of 13 years in our case seems short in comparison to the relevant literature, it is consistent with the data published by Ghim et al. (10.8 years), where the patients were exposed to radiation at early ages [26].

Surgical removal of these lesions is the first treatment of choice. Radiation-induced meningiomas have a tendency to recur, but it is a known fact that recurrence is one of the main problems related to skull base meningiomas even without a radiation effect. Despite total surgical removal, recurrence may occur and in that case anatomical barriers do not have an influence on tumours growth [27]. So, dissection of these recurrent tumours from vital anatomical structures is challenging. Also in our case, recurrence occurred within 15 months despite total surgical removal. Complete removal of recurrent radiation-induced meningiomas is not always possible due to the aggressive nature of the tumour and due to prior radiotherapy. The tendency for multiple lesions, and bone and vascular involvement makes total surgical removal impossible in certain recurrent cases as well as in our case.

Interestingly, patients with radiation-induced meningiomas may benefit from radiotherapy or stereotactic radiosurgery, although these tumours were induced by radiation therapy. However, because of the former highdose radiation exposure of our patient and the size of the irradiation field, stereotactic radiosurgery or conventional radiotherapy was not considered as a treatment option. With systemic chemotherapy, 15 -month survival was achieved until the recurrence. After resection of the recurrent meningioma, additional systemic chemotherapy was planned.

In the treatment of malignant diseases of childhood such as lymphoma, leukaemia, gliomas, retinoblastoma and medulloblastoma, great progress in the survival rates has been achieved with combined oncological treatment modalities. Despite the advances in radiation dose delivery technologies, still total radiation doses as high as 50-60 Gy are delivered to the patients for longer survival [28]. As the patients' disease-free survival gets longer, new problems occur, such as radiation necrosis or radiation-induced tumours. We believe that the actual incidence of this pathology is higher than it was reported earlier in the literature and in the future it will become a more serious problem in the management of cranially irradiated patients.

\section{Disclosure}

Authors report no conflict of interest.

\section{References}

1. Pettorini L.B., Park Y.-S., Caldarelli M., et al. Radiationinduced brain tumours after central nervous system irradiation in childhood: a review. Childs Nerv Syst 2008; 24: 793-805.

2. Salvati M., D'Elia A., Melone G.A., et al. Radio-induced gliomas: 20-year experience and critical review of the pathology. J Neurooncol 2008; 89: 169-177.

3. Umansky F., Shoshan Y., Rosenthal G., et al. Radiation-induced meningioma. Neurosurg Focus 2008; 24: E7.

4. Al-Mefty O., Topsakal C., Pravdenkova S., et al. Radiationinduced meningiomas: clinical, pathological, cytokinetic, and cytogenetic characteristics. J Neurosurg 2004; 100: 1002-1013.

5. Harrison M.J., Wolfe D.E., Lau T.S., et al. Radiation-induced meningiomas: experience at the Mount Sinai Hospital and review of the literature. J Neurosurg 1991; 75: 564-574.

6. Malde R., Jalali R., Muzumdar D., et al. Gliosarcoma occurring 8 years after treatment for a medulloblastoma. Childs Nerv Syst 2004; 20: 243-246.

7. Nishio S., Morioka T., Inamura T., et al. Radiation-induced brain tumours: potential late complications of radiation therapy for brain tumours. Acta Neurochir (Wien) 1998; 140: 763-770.

8. Yilmaz A., Musluman M., Aydın Y. Primary osteolytic intraosseous meningioma of the frontal bone. Neurol Neurochir Pol 2010; 44: 415-418.

9. Cantini R., Giorgetti W., Valleriani A.M., et al. Radiation-induced cerebral lesions in childhood. Childs Nerv Syst 1989; 5: 135-139.

10. Caroli E., Russillo M., Ferrante L. Intracranial meningiomas in children. Report of 27 new cases and critical analysis of 440 cases reported in the literature. J Child Neurol 2006; 21: 31-36.

11. Mehta N., Bhagwati S., Parulekar G. Meningiomas in children: a study of 18 cases. J Pediatr Neurosci 2009; 4: 61-65.

12. Knudson A.G. Mutation and cancer. Statistical study of retinoblastoma. Proc Natl Acad Sci USA 1971; 68: 820-823.

13. Lee W.H., Bookstein R., Hong F., et al. Human retinoblastoma susceptibility gene: cloning, identification, and sequence. Science 1987; 235: 1394-1399. 
14. Balik V., Sarissky M., Lohmann D., et al. Meningioma 40 years after radiation therapy for retinoblastoma: genetic and phenotypic analysis and minireview of literature. Zentralbl Neurochir 2008; 69: 194-199.

15. Draper G.J., Sanders B.M., Kingston J.E. Second primary neoplasms in patients with retinoblastoma. Br J Cancer 1986; 53: 661-671.

16. Kadasheva A.B., Cherekaev V.A., Kozlov A.V., et al. Meningiomas of the wings of the basilar bone in patients undergone a course of radiation therapy for retinoblastoma in infancy (analysis of 3 cases). Zh Vopr Neirokhir Im N N Burdenko 2004; 3: 24-27.

17. Karjalainen K., Tarkkanen A., Merenmies L. Suprasellar meningioma 47 years after bilateral retinoblastoma. Acta Ophthalmol 1988; 66: 79-82.

18. Kleinermann R.A., Tucker M.A., Tarone R.E., et al. Risk of new cancer after radiatherapy in long term survivors of retinoblastoma: an extended follow-up. J Clin Oncol 2005; 23: 2272-2279.

19. Moss S.D., Rockswold G.L., Yock D., et al. Radiation-induced meningiomas in pediatric patients. Neurosurgery 1988; 22: 758-761.

20. Musa B.S., Pople I.K., Cummins B.H. Intracranial meningiomas following irradiation - a growing problem? BrJ Neurosurg 1995; 9: 629-637.

21. Shibui S., Nomura K., Matsuoka K., et al. Two cases of the middle fossa tumor following radiotherapy against retinoblastoma. No Shinkei Geka 1987; 15: 1087-1091.

22. Cahan W.G., Woodard H.Q., Higinbotham N.L., et al. Sarcomas arising in irradiated bone. Report of eleven cases. Cancer 1948; 1: 3-29.

23. Makidono A., Kobayashi N., Saida Y., et al. Metachronous gliomas following cranial irradiation for mixed germ cell tumors. Childs Nerv Syst 2009; 25: 713-718.

22. Robinson L.L., Bhatia S. Late-effects among survivors of leukemia and lymphoma during childhood and adolescence. Br J Haematol 2003; 122: 345-359.

25. Carret A.S., Tabori U., Crooks B., et al. Outcome of secondary high-grade glioma in children previously treated for a malignant condition: a study of the Canadian Pediatric Brain Tumour Consortium. Radiother Oncol 2006; 81: 33-38.

26. Ghim T.T., Seo J.J., O'Brien M., et al. Childhood intracranial meningiomas after high-dose irradiation. Cancer 1993; 71: 40914095 .

27. Ladzinski P., Majchrzak H., Kaspera W., et al. Medial sphenoid ridge meningiomas: early and long-term results of surgical removal using the fronto-temporo-orbito-zygomatic approach. Neurol Neurochir Pol 2010; 44: 464-474.

28. Sharma D.N., Goyal S., Muzumder S., et al. Radiation therapy in pediatric gliomas: our instutional experience. Neurol Neurochir Pol 2010; 44: 28-34 